\title{
TECHNICAL AND ECONOMIC INDICATORS OF THE YELLOW PASSION FRUIT TREE IRRIGATED WITH UNDERGROUND WATER SUPPLY
}

\author{
HAROLDO F. DE ARAÚJO ${ }^{1}$, RAIMUNDO N. T. COSTA ${ }^{2}$, JOÃO R. CRISÓSTOMO ${ }^{3}$, LUÍS \\ CARLOS U. SAUNDERS ${ }^{4}$, OLAVO DA C. MOREIRA ${ }^{5}$
}

\begin{abstract}
The research aimed to quantify technical and economic indicators of yellow passion fruit tree irrigated with fractions of irrigation with underground source of water, to generate information that helps farmers in decision making on the implementation of investment in irrigated fruit growing (yellow passion fruit). For this purpose, we used the passion fruit crop irrigated with Microjet type irrigation system, with conducting system in simple espaliers. The treatments consisted of five hours of application of the depth of water required by the crop with irrigation frequency of two days. The results showed that the highest yield $\left(16660 \mathrm{~kg} \mathrm{ha}^{-1}\right)$ was obtained with the fractionation of irrigation twice a day (50\% to $7 \mathrm{~h}$ and $50 \%$ to $21 \mathrm{~h} 30$ ), which provided an increase in productivity of $54 \%$, demonstrating the financial viability and being highly profitable to the interest rate of $2 \%$ per year, with low sensitivity of financial risk to real interest rates above the prevailing market.
\end{abstract}

KEYWORDS: Passiflora edulis, Productivity, Night irrigation, Profitability analysis.

\section{INDICADORES TÉCNICOS E ECONÔMICOS DO MARACUJAZEIRO AMARELO IRRIGADO COM FONTE DE ÁGUA SUBTERRÂNEA}

RESUMO: O trabalho teve como objetivo quantificar indicadores técnicos e econômicos do maracujazeiro-amarelo irrigado com fracionamento da irrigação com fonte de água subterrânea, de forma a gerar informações que auxiliem os agricultores na tomada de decisão sobre a aplicação de seus investimentos na fruticultura irrigada (maracujá-amarelo). Para tanto, utilizou-se da cultura do maracujá, irrigado com sistema de irrigação tipo microjet, sob a forma de condução em espaldeiras simples. Os tratamentos constaram da combinação de horários de aplicação da lâmina de água requerida pela cultura, com frequência de irrigação de dois dias. Os resultados permitiram concluir que a maior produtividade $\left(16.660 \mathrm{~kg} \mathrm{ha}^{-1}\right)$ foi obtida com o fracionamento da irrigação em duas vezes ao dia (50\% às $7 \mathrm{~h}$ e $50 \%$ às $21 \mathrm{~h} 30)$, a qual proporcionou um incremento de produtividade de $54 \%$, demonstrando viabilidade do ponto de vista financeiro e altamente lucrativo à taxa de juros de $2 \%$ ao ano, com baixa sensibilidade de risco financeiro a taxas reais de juros acima das praticadas no mercado.

PALAVRAS-CHAVE: Passiflora edulis, Produtividade, Irrigação noturna, Análise de rentabilidade.

\section{INTRODUCTION}

In the last decades, there was a significantly increase in irrigated fruit growing in Brazilian agriculture, achieving great strides with regard to the economy and efficiency of use of water applied by irrigation, especially in the Northeast region, where cultivation is restricted to the use of irrigation (ARAÚJO et al., 2012). Being a financially profitable crop to the farmer family and securing a well distributed source of income throughout the year, the culture of irrigated passion fruit has been outstanding, especially in the Northeast region because this region provides

\footnotetext{
${ }^{1}$ Doutorando em Engenharia Agrária, Feagri/Unicamp, haroldfa@ gmail.com.

${ }^{2}$ Professor Associado IV, Doutor, Departamento de Engenharia Agrícola, UFC, Fortaleza,CE, rntcosta@ufc.br.

${ }^{3}$ Pesquisador aposentado, Embrapa Agroindústria Tropical, Fortaleza, CE; crisostomo@ cnpat.embrapa.br.

${ }^{4}$ Professor aposentado, Doutor, Departamento de Engenharia Agrícola, UFC, Fortaleza,CE; pradmufc@ufc.br.

${ }^{5}$ Mestrando em Engenharia Agrícola, UFC, Fortaleza,CE; moreira_olavo@ yahoo.com.br.

Recebido pelo Conselho Editorial em: 3-8-2011
}

Aprovado pelo Conselho Editorial em: 15-5-2013 
environmental conditions favorable to the development of the crop. For these reasons, the region's farmers are beginning to make feasible techniques that enable higher productivity and product quality (CARVALHO et al., 2010).

The passion fruit production in Brazil has increased in recent years due to attractive prices, especially in the fresh fruit market. Currently, Brazil is the largest producer of this culture, corresponding to a total production of 920 million tonnes with an average yield of $15.34 \mathrm{t} \mathrm{ha}^{-1}$, with emphasis on the Northeast region with $76 \%$ of national production, and Southeast region with $13.85 \%$ (IBGE, 2010).

According to CARVALHO et al. (2010), most of the passion fruit producing regions in Brazil still have very low income relative to other producing countries, due to lack of appropriate technology.

Although the Northeast region offer favorable soil and climatic conditions for the cultivation of most fruits, the annual rainfall is unevenly distributed during the rainy season, a factor that limits their cultivation, mainly because it requires a good amount of water in stages of flowering and fruit set (CARVALHO et al., 2010). AREDES et al. (2009) exempt that in areas that have temperature, soil and water conditions favorable for the cultivation of the fruit, the use of irrigation in the cultivation of passion fruit is doubtful because in these regions the irrigation practices are supplementary and its economic viability can be discussed.

Irrigation is an essential technique for establishing orchards of fruit crops in the Northeast region, ensuring the crop water requirements (SANTANA et al., 2008), but in times of drought, the power consumption increases considerably due to the increase of the irrigation time for crops.

To improve the utilization of energy available, the hour seasonal rates were created exclusively for use in irrigation in an attempt to optimize the power consumption and promote consumption at times and periods of lower demand and higher supply (RIBEIRO et al., 2010.) According to the Department of Agrarian Development (SDA, 2009), the effective reduction in the energy bill can reach $73 \%$, a significant reduction in the production costs of the crop. According to the same department, in recent years, through government incentives there has been a considerable increase in farmers exploring the irrigated fruit growing as an alternative to diversify production and income in their properties but without information on the technical and economic indicators that shows them financial return on the investments made.

Currently, there are few researches demonstrating the productive and economic viability of the production of fruits, combining day and night hours of irrigation, especially in the evening hours. Thus, in order to supply the lack of information about the productive and economic viability of irrigation schedules using alternative water source of lower quality (underground water) in the culture of yellow passion fruit, this study was carried out in order to quantify the technical indicators and economic aspects of cultivation of the yellow passion fruit tree irrigated with fractions of irrigation with underground water source, to generate information to assist farmers in decision making on the implementation of their investments in irrigated fruit (yellow passion fruit).

\section{MATERIAL AND METHODS}

The experiment was conducted from September 2009 to August 2010, corresponding to the first cycle of crop production in an area of $24 \mathrm{~m} \times 58 \mathrm{~m}$, located in Sector C, Lot 07, in the Curu Pentecoste Irrigation Perimeter - located in the state of Ceará (CE), Brazil. The climate type in the region, according to the Köppen classification, is BSw'h', belonging to the group of semi-arid climate, with average annual rainfall of $797.0 \mathrm{~mm}$ concentrated in the months from January to April, average annual temperature with maximum of $33,4^{\circ} \mathrm{C}$ and minimum of $22.4^{\circ} \mathrm{C}$, relative air humidity of $80 \%$ and monthly average evaporative demand of $120 \mathrm{~mm}$.

In the area of the experiment the soil is classified as NEOSOL with relief typically flat and sandy loam textural classification. The physical and chemical characterization of the soil layer from 
$0.00 \mathrm{~m}$ to $0.30 \mathrm{~m}$ (Table 1) was performed at the Laboratory of Soil and Water Analysis of the Federal University of Ceará (UFC). The values of the physical and chemical attributes show that is a soil with predominance of fine sand with low organic matter content. Therefore, it have low available water capacity in the root zone of the crop $(12.8 \mathrm{~mm})$, thus requiring a higher frequency of irrigation, as suggested by (SAEED \& EL-NADI, 1997). The $\mathrm{pH}$ is presented outside the ideal range for culture (6.0 to 6.5) but the base saturation is in the ideal range of $80 \%$, as recommended by BORGES (2004) for the conditions of the Brazilian Northeast region.

TABLE 1. Physical and chemical characteristics of soil in the experimental area.

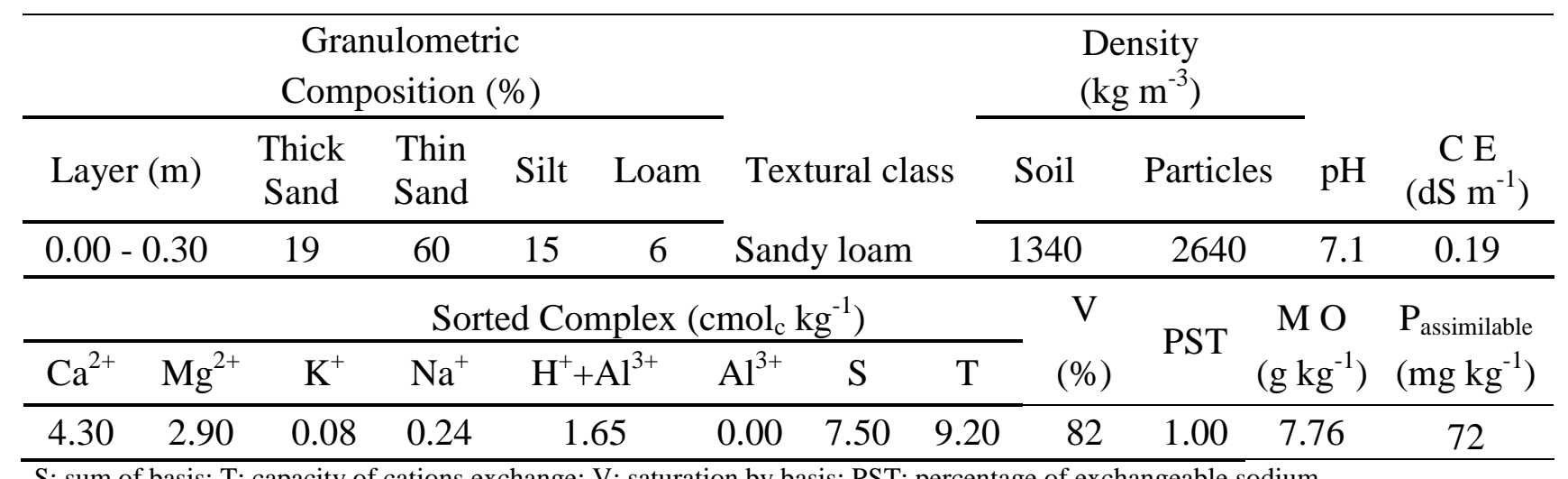

S: sum of basis; T: capacity of cations exchange; V: saturation by basis; PST: percentage of exchangeable sodium.

The soil preparation consisted of a hand mowing, plowing and harrowing. The pits were opened at a spacing of $2.5 \mathrm{~m} \times 4.0 \mathrm{~m}$ in dimensions of $0.4 \mathrm{~m} \times 0.4 \mathrm{~m} \times 0.4 \mathrm{~m}$ getting $10 \mathrm{~L}$ of bovine manure as a source of organic matter, $0,054 \mathrm{~kg}$ of $\mathrm{P}_{2} \mathrm{O}_{5}$ as simple superphosphate, $0.20 \mathrm{~kg}$ of dolomitic limestone and $0.05 \mathrm{~kg}$ of FTE BR 12 .

The fertilizations of formation and production, with nitrogen and potassium, followed the recommendation of BORGES (2004), being held through fertilization by coverage. In the formation phase of the culture (up to 120 days after transplanting), we applied four fertilizations in the form of ammonium sulfate to the nitrogen source and three fertilizations in the form of potassium chloride to potassium source, the first fertilization was performed 30 days after transplanting, only with $\mathrm{N}$ $\left(0.010 \mathrm{~kg} \mathrm{~N}\right.$ plant $\left.^{-1}\right)$.

At 60, 90 and 120 days after transplanting we made the other fertilizations in coverage , using $0.020,0.030$ and $0.040 \mathrm{~kg} \mathrm{~N}$ plant $^{-1}$ year $^{-1}$ respectively. Also, at 60 days after transplanting we proceeded to potassium fertilizer with $0.010,0.020$ and $0.030 \mathrm{~kg} \mathrm{~K}_{2} \mathrm{O}$ plant $^{-1}$ year $^{-1}$, following the recommendation of BORGES (2004) and analysis of soil of the area.

The irrigation system used was the microaspersion of Microjet type, with two emitters per plant and flow rate of $14 \mathrm{~L} \mathrm{~h}^{-1}$ each. The water source that fed the irrigation system was derived from a shallow tubular well located near the area of the experiment, which had water with electrical conductivity (CE) of $1.05 \mathrm{dS} \mathrm{m}^{-1}$ and RAS 2.59, classified as $\mathrm{C}_{3} \mathrm{~S}_{1}$, that is, have a medium risk of salinity $\left(\mathrm{C}_{3}\right)$, and there is no risk of sodification $\left(\mathrm{S}_{1}\right)$. The risk of clogging of drippers is considered moderate in chemical and physical aspects.

The experimental delineation was randomized blocks with five treatments and four replications. The treatments consisted of application times of the water depth required by the crop (LR), with irrigation frequencies of two days, distributed in: $\mathrm{T}_{1}: 100 \%$ of LR ar $7 \mathrm{~h} ; \mathrm{T}_{2}: 50 \%$ of LR at $07 \mathrm{~h}$ and $50 \%$ of LR at $15 \mathrm{~h} ; \mathrm{T}_{3}: 25 \%$ of LR at $7 \mathrm{~h} ; 50 \%$ of LR at $15 \mathrm{~h}$ and $25 \%$ of LR at $21 \mathrm{~h} 30 ; \mathrm{T}_{4}$ : $100 \%$ of LR at $21 \mathrm{~h} 30: \mathrm{T}_{5}: 50 \%$ of LR at $07 \mathrm{~h}$ and $50 \%$ of LR at $21 \mathrm{~h} 30$.

The water depth required was calculated from the data of evaporation from a Class A Tank (ECA) installed near the experimental area, associated with the installation conditions and its cultivation coefficient of the culture. The treatment effect was analyzed based only on the variable productivity of the commercial culture, calculating from this the profitability indicators of 
investment analysis (benefit/cost ratio, present net value and internal rate of return), beyond the period of "playback" to a horizon of eight years.

In the study it was considered that the farmer obtained funding for investment by the National Program for Strengthening Family Agriculture (Pronaf), in the group of Common Pronaf that has term of up to eight years and a grace period for payment of up to three years at an interest rate of $2 \%$ per year for an investment of R \$ 7,000.00 to 18,000.00 (SEBRAE, 2010).

The loan made by the farmer was the amount of $\mathrm{R} \$ 18,000.00$. Therefore, the analysis was "ex-ante" and "ex-post". All prices used in the economic analysis, products or inputs, were gathered from the region itself, to reflect the real economic potential of the alternatives tested. The water cost $\left(\mathrm{R} \$ \mathrm{~mm}^{-1}\right)$, given that the implementation costs are included in the production costs of the crop, was considered equal to the electricity tariff, which is formed by the sum of the cost of energy effective consumption and demand cost of electric power. According to the rules of ANEEL (Brazilian National Electric Energy Agency), there is tariff of demand only when the power capacity installed exceeds $75 \mathrm{KVA}$. Given that for the conditions of the study the system operated with an inferior installed capacity, using a $4.0 \mathrm{hp}$ electric motor to irrigate one hectare, the cost of demand was zero, and the rate of energy was comprised only by the cost of consumption.

The cost of electricity consumption was estimated based on equation 01 , as presented by MONTEIRO et al. (2007).

$$
\mathrm{CE}=0.7457 \times \text { Pot } \mathrm{x} \text { Tf } \times \mathrm{P}(\mathrm{kwh})
$$

In which: CE: cost of electricity during the crop cycle in $\mathrm{R} \$$; 0.7457 : conversion factor from $\mathrm{hp}$ to $\mathrm{kW}$; Pot: engine power in hp; Tf: time of functioning of system needed to replace the ECA, in hours, during one year, considering an irrigated area of 1ha, which was 335.59 hours year; Pkwh: kwh price in $\mathrm{R} \$$.

The price of kwh was obtained with the COELCE (Energy Company of Ceará) and refers to the value of $1.0 \mathrm{kWh}$ considering that the system worked at times established in treatment for peak hours and evening hours. Therefore, the price of kwh used at peak hours was $\mathrm{R} \$ 0.27$ and the evening hours at $\mathrm{R} \$ 0.07$.

The annual real interest rate was $2 \%$ per year, as funding from the group Common Pronaf. We considered also that the equipment would have a useful life of eight years, being null its residual value at the end of its useful life. 02.

Calculating the current value, we used a discount factor (FD), which is expressed by equation

$$
F D=\left(1 /\left(1+r^{\wedge} i\right)\right)
$$

In which: r: real annual interest rate (decimal); i: number of years to pay off the investment or equipment life.

The profitability indicators of the investment analysis were calculated according to the following equations:

Benefit Cost Ratio (B/C): expresses the relationship between the present value of revenues to be obtained and the present value of costs (including investments), calculated by equation 03 .

$$
B / C=\left(\sum_{i=0}^{n} R i /(1+r)^{i} / \sum_{i=0}^{n} C i /(1+r)^{i}\right)
$$

In which: Ri: revenue obtained in the year, in $\mathrm{R} \$$; $\mathrm{r}$ : real annual interest rate (decimal); $\mathrm{i}$ : number of years to pay off the investment or equipment life; $\mathrm{Ci}$ : costs in the year, in $\mathrm{R} \$$. 
Net Present Value (VPL): Consists in transfer to the present moment all the variations of expected cash, cashing them at a certain interest rate, and add them algebraically, represented by the present value of Net Benefits (benefits/costs), calculated by equation 04.

$$
V P L=\sum_{i=0}^{n}(R i-C i) /(1+r)^{i}=\sum_{i=0}^{n} R i /(1+r)^{i}-\sum_{i=0}^{n} C i /(1+r)^{i}
$$

In which: Ri: revenue obtained in the year, in $\mathrm{R} \$$; $\mathrm{r}$ : real annual interest rate (decimal); $\mathrm{i}$ : number of years to pay off the investment or equipment life; $\mathrm{Ci}$ : costs in the year, in $\mathrm{R} \$$.

Internal Rate of Return (TIR): Expresses the percentage of average annual profitability of capital allocated throughout the analysis horizon, therefore being a rate that anull the VPL of cash flow investment, thus characterizing the rate of return of the capital invested, calculated by equation 05 .

$$
\mathrm{VPL}=\sum_{i=0}^{n}(R i-C i) /(1+r)^{i}=0
$$

In which: Ri : revenue achieved in the year, in $\mathrm{R} \$$; $r$ : real annual interest rate (decimal); $\mathrm{i}$ : number of years to pay off the investment or equipment life $\mathrm{Ci}$ : costs in the year, in $\mathrm{R} \$$.

The average price per kilogram of passion fruits in production period was $\mathrm{R} \$ 1.14$, and is considered the year (1), equal to the year (0) as the grace period as the beginning of crop production.

In the performed investment analysis, we considered the production from the first cycle or the first year constant for the eight years of analysis, however is known by the literature presented by AREDES et. al. (2009); ARAUJO NETO et al. (2005), CARVALHO et al. (2010), and other researchers, in the second production cycle, the yield tends to increase considerably, and may double compared to the first cycle. Thus, it is guaranteed that the investment analysis done in this study, show the producer the real dimension of his financial application, logically without considering the risks of production.

The operating costs (fixed and variable) were considered for the implantation of a hectare of irrigated agriculture and worked by the family, being considered only two years or two production cycles. After those two years we considered the implantation of a new cultivation, but considering only the variable costs depending on the treatments used.

In the first year of production, we considered fixed and variable costs for implantation of culture as an investment, and considered only the interest on the debt service, since this year was considered year 0 , or grace. In the second year of production we considered variable costs for maintenance of cultivation, in addition to the costs for start of amortization and debt service. From the third year of production, we considered the variable costs for implantation of a new cultivation, plus amortization and debt service. Thus, the cost values (variables) for the remaining years of production were being alternated in between the values of the second and third year of production.

The fruit harvest started on 04/24/2010 and was extended to 07/20/2010 (87 days), end of the 1st cycle. The harvests occurred weekly, being the fruits harvested at the preclimacteric stage, characterized by the change from green to yellow, and the fruit that fell spontaneously. The business productivity data, number of fruits per plant and fruit weight were subjected to analysis of variance and comparison of means by the Tukey test at 5\% and $1 \%$ probability, using ASISTAT Software, version 7.5 beta 2011 .

\section{RESULTS AND DISCUSSION}

The results of the analysis of variance contained in Table 2 show statistical significance at the $1 \%$ level of probability for the variables yield and number of fruits per plant and $5 \%$ for the average fruit weight. We observed that the culture responded differently to the systematic management of 
irrigation at different times. The same was not observed by CARVALHO et al. (2010), using different ways to the systematic management of irrigation, but with different voltages applied to the soil water.

This difference observed seems to the producer a good alternative to reduce production costs with electricity and water loss by evaporation promoted by drift caused by wind during daytime irrigation. This is because, usually at night, the speed of wind is lower, as the temperature and therefore the deviations from irrigation water applied. Given a higher relative humidity of air during this period, we have lower water loss and therefore an increase in the efficiency of water use, constituting an environmentally correct practice.

TABLE 2. Analysis of variance for yield (PRODT), fruit number per plant $\left(\mathrm{N} \mathrm{F} \mathrm{P}^{-1}\right)$ and average fruit weight (P M F).

\begin{tabular}{ccccc}
\hline \multirow{2}{*}{ Variation Source } & \multirow{2}{*}{ GL } & \multicolumn{3}{c}{ Average Squares } \\
\cline { 3 - 5 } & & PRODT & $\mathrm{N} \mathrm{F} \mathrm{P}^{-1}$ & P M F \\
\hline Blocks & 3 & 6.473 & 55.783 & 816.88 \\
Treatments & 4 & $39.545^{* *}$ & $614.175^{* *}$ & $1741.350^{*}$ \\
Residues & 12 & 2.296 & 75.742 & 332.65 \\
CV & & 13.165 & 16.252 & 8.64 \\
\hline
\end{tabular}

**Significative at level of $1 \%$ of probability $(\mathrm{p}<, 01)$ by the $\mathrm{F}$ test; $*$ Significative at level of $5 \%$ of probability $(\mathrm{p}<, 05)$ by the $\mathrm{F}$ test.

Table 3 presents the mean comparisons among treatments. We can see that in treatment $\mathrm{T}_{5}$, whose productivity was of $16.66 \mathrm{t} \mathrm{ha}^{-1}$, with irrigation fractionated twice daily with applications of $50 \%$ of the depth required in the morning and 50\% at night, the number of variables and productivity fruits per plant showed statistical differences compared to the other treatments, although they have not shown statistically significant differences between them.

TABLE 3. Tukey test to compare the means of productivity, number of fruits per plant and average fruit weight.

\begin{tabular}{cccc}
\hline Treatments & PRODT & $\mathrm{NF} \mathrm{P}^{-1}$ & P M F \\
\hline $\mathrm{T}_{1}$ & $11.67 \mathrm{~b}$ & $53 \mathrm{~b}$ & $219.71 \mathrm{a}$ \\
$\mathrm{T}_{2}$ & $11.30 \mathrm{~b}$ & $55 \mathrm{~b}$ & $204.57 \mathrm{ab}$ \\
$\mathrm{T}_{3}$ & $8.95 \mathrm{~b}$ & $46 \mathrm{~b}$ & $177.38 \mathrm{~b}$ \\
$\mathrm{~T}_{4}$ & $8.97 \mathrm{~b}$ & $42 \mathrm{~b}$ & $226.27 \mathrm{a}$ \\
$\mathrm{T}_{5}$ & $16.66 \mathrm{a}$ & $74 \mathrm{a}$ & $227.14 \mathrm{a}$ \\
\hline Means & 11.51 & 54 & 211.01 \\
\hline
\end{tabular}

Means followed by the same letter do not differ statistically at level $5 \%$ by the Tukey test.

It was found that the highest values of the analyzed variables are associated with treatment $\mathrm{T}_{5}$, certainly due to a shorter period of water depletion in the soil between the two consecutive irrigations, compared to the other treatments. According to MENEGHETTI et al. (2008) the irrigation management with more frequency in the application of water make the soil maintain optimal water content, favoring better crop development and keeping it without water deficit stress.

CARVALHO et al. (2010), working with yellow passion fruit cultivation in an protected and natural environment with different irrigation depths, found that irrigating the threshold voltage of $15 \mathrm{kPa}$ the plants kept in adequate condition for soil moisture, near field capacity, favoring vegetative growth of the crop. 
The average productivity of the culture by the treatments shown in Table 3 shows that the maximum yield $\left(16.66 \mathrm{t} \mathrm{ha}^{-1}\right.$ ) obtained in the $\mathrm{T}_{5}$ treatment was higher in $11.8 \%$ to the yield obtained by SOUZA et al. (2009), whose study was conducted in the same region, with the control of irrigation performed by the tensiometer with tension of $35 \mathrm{kPa}$. As productivity, the highest number of fruits per plant was also observed in treatment $\mathrm{T}_{5}$, which does not have a direct correlation, as this variable is greatly affected by the average fruit weight, as found by ARAÚJO NETO et al. (2005) in a study with different densities of cultivation.

CARVALHO et al. (2010) found a mean value of commercial yield of $67.70 \mathrm{t} \mathrm{ha}^{-1}$ for protected environment and $68.25 \mathrm{tha}^{-1}$ for the natural environment, well above the national average $\left(13.39 \mathrm{t} \mathrm{ha}^{-1}\right)$. According to the authors, this high productivity is related to proper fertilization, to water depth applied, to appropriate treatments and to crowding of the culture, combined with the climate of the area where the research was conducted.

Table 4 presents the economic elements for the calculation of the profitability indicators for each of the treatments, considering a horizon of eight years. Revenues were composed by the gross value of production (VBP), which corresponds to the price per $\mathrm{kg}$ of fruit multiplied by the productivity values for each treatment contained in Table 3 . Thus, we can financially see the profitability of each treatment, regardless of their statistical significance, which will assist the producer in decision making in choosing which treatment to use in their production, taking into account the cost of labor and financial return generated for each treatment.

TABLE 4. Data for the calculation of the profitability indicators. Treatment $\mathrm{T}_{1}$.

\begin{tabular}{cccccc}
\hline Years & \multicolumn{2}{c}{ Nominal Values $(\mathrm{R} \$)$} & $\mathrm{F} \mathrm{D}(\mathrm{r}=2 \%)$ & \multicolumn{2}{c}{ Up-to-date Values $(\mathrm{R} \$)$} \\
\hline & C. oper. + Debt S. & Gross Revenue & & Total C. & Gross Income \\
\hline 1 & 351.57 & 13301.75 & 1.0000 & 351.57 & 13301.75 \\
2 & 8942.13 & 13301.75 & 0.9804 & 8766.80 & 13040.93 \\
3 & 9043.88 & 13301.75 & 0.9612 & 8692.69 & 12785.23 \\
4 & 8841.69 & 13301.75 & 0.9423 & 8331.72 & 12534.54 \\
5 & 8943.43 & 13301.75 & 0.9238 & 8262.35 & 12288.76 \\
6 & 8741.24 & 13301.75 & 0.9057 & 7917.21 & 12047.80 \\
7 & 8842.98 & 13301.75 & 0.8880 & 7852.32 & 11811.57 \\
8 & 8640.79 & 13301.75 & 0.8706 & 7522.33 & 11579.97 \\
\hline Total & 62347.71 & 106414.00 & & 57696.98 & 99390.56
\end{tabular}

F D: Factor of discount; r: interest rate; Oper C.: operational costs=Total C.: Total costs.

Treatment $\mathrm{T}_{2}$.

\begin{tabular}{|c|c|c|c|c|c|}
\hline \multirow{2}{*}{ Years } & \multicolumn{2}{|c|}{ Nominal Values (R\$) } & \multirow{2}{*}{$\mathrm{F} \mathrm{D}(\mathrm{r}=2 \%)$} & \multicolumn{2}{|c|}{ Up-to-date Values (R\$) } \\
\hline & C. oper. + Debt S. & Revenue & & Total C. & Income \\
\hline 1 & 351.57 & 12883.94 & 1.0000 & 351.57 & 12883.94 \\
\hline 2 & 8942.13 & 12883.94 & 0.9804 & 8766.80 & 12631.31 \\
\hline 3 & 9043.88 & 12883.94 & 0.9612 & 8692.69 & 12383.64 \\
\hline 4 & 8841.69 & 12883.94 & 0.9423 & 8331.72 & 12140.82 \\
\hline 5 & 8943.43 & 12883.94 & 0.9238 & 8262.35 & 11902.77 \\
\hline 6 & 8741.24 & 12883.94 & 0.9057 & 7917.21 & 11669.38 \\
\hline 7 & 8842.98 & 12883.94 & 0.8880 & 7852.32 & 11440.57 \\
\hline 8 & 8640.79 & 12883.94 & 0.8706 & 7522.33 & 11216.25 \\
\hline Total & 62347.71 & 103071.52 & - & 57696.98 & 96268.68 \\
\hline
\end{tabular}

F D: Factor of discount; r: interest rate; Oper C.: operational costs=Total C.: Total costs. 
Treatment $\mathrm{T}_{3}$.

\begin{tabular}{|c|c|c|c|c|c|}
\hline \multirow{2}{*}{ Years } & \multicolumn{2}{|c|}{ Nominal Values $(\mathrm{R} \$)$} & \multirow{2}{*}{$\mathrm{F} \mathrm{D}(\mathrm{r}=2 \%)$} & \multicolumn{2}{|c|}{ Up-to-date Values (R\$) } \\
\hline & C. oper. + Debt S. & Revenue & & Total C. & Income \\
\hline 1 & 350.56 & 10206.99 & 1.0000 & 350.56 & 10206.99 \\
\hline 2 & 8883.92 & 10206.99 & 0.9804 & 8709.72 & 10006.85 \\
\hline 3 & 8985.80 & 10206.99 & 0.9612 & 8636.87 & 9810.64 \\
\hline 4 & 8783.75 & 10206.99 & 0.9423 & 8277.13 & 9618.27 \\
\hline 5 & 8885.64 & 10206.99 & 0.9238 & 8208.96 & 9429.68 \\
\hline 6 & 8683.59 & 10206.99 & 0.9057 & 7865.00 & 9244.79 \\
\hline 7 & 8785.48 & 10206.99 & 0.8880 & 7801.25 & 9063.52 \\
\hline 8 & 8583.43 & 10206.99 & 0.8706 & 7472.39 & 8885.80 \\
\hline Total & 61942.18 & 81655.92 & - & 57321.89 & 76266.54 \\
\hline
\end{tabular}

F D: Factor of discount; r: interest rate; Oper C.: operational costs=Total C.: Total costs.

Treatment $\mathrm{T}_{4}$.

\begin{tabular}{ccccccc}
\hline \multirow{2}{*}{ Years } & \multicolumn{2}{c}{ Nominal Values $(\mathrm{R} \$)$} & \multirow{2}{*}{$\mathrm{F} \mathrm{D}(\mathrm{r}=2 \%)$} & \multicolumn{2}{c}{ Up-to-date Values $(\mathrm{R} \$)$} \\
\cline { 2 - 3 } & C. oper. + Debt S. & Revenue & & Total C. & Income \\
\hline 1 & 347.56 & 10225.12 & 1.0000 & 347.56 & 10225.12 \\
2 & 8709.26 & 10225.12 & 0.9804 & 8538.49 & 10024.63 \\
3 & 8811.58 & 10225.12 & 0.9612 & 8469.41 & 9828.07 \\
4 & 8609.95 & 10225.12 & 0.9423 & 8113.35 & 9635.36 \\
5 & 8712.27 & 10225.12 & 0.9238 & 8048.79 & 9446.43 \\
6 & 8510.65 & 10225.12 & 0.9057 & 7708.36 & 9261.21 \\
7 & 8612.97 & 10225.12 & 0.8880 & 7648.07 & 9079.61 \\
8 & 8411.35 & 10225.12 & 0.8706 & 7322.59 & 8901.58 \\
\hline Total & 60725.59 & 81800.96 & - & 56196.62 & 76402.01 \\
\hline
\end{tabular}

F D: Factor of discount; r: interest rate; Oper C.: operational costs=Total C.: Total costs.

Treatment $\mathrm{T}_{5}$.

\begin{tabular}{|c|c|c|c|c|c|}
\hline \multirow{2}{*}{ Years } & \multicolumn{2}{|c|}{ Nominal Values (R\$) } & \multirow{2}{*}{$\mathrm{F} \mathrm{D}(\mathrm{r}=2 \%)$} & \multicolumn{2}{|c|}{ Up-to-date Values $(\mathrm{R} \$)$} \\
\hline & C. oper. + Debt S. & Revenue & & Total C. & Income \\
\hline 1 & 349.56 & 18988.41 & 1.0000 & 349.56 & 18988.41 \\
\hline 2 & 8825.70 & 18988.41 & 0.9804 & 8652.64 & 18616.09 \\
\hline 3 & 8927.73 & 18988.41 & 0.9612 & 8581.05 & 18251.07 \\
\hline 4 & 8725.82 & 18988.41 & 0.9423 & 8222.54 & 17893.20 \\
\hline 5 & 8827.85 & 18988.41 & 0.9238 & 8155.57 & 17542.36 \\
\hline 6 & 8625.95 & 18988.41 & 0.9057 & 7812.79 & 17198.39 \\
\hline 7 & 8727.98 & 18988.41 & 0.8880 & 7750.19 & 16861.16 \\
\hline 8 & 8526.07 & 18988.41 & 0.8706 & 7422.46 & 16530.55 \\
\hline Total & 61536.66 & 151907.28 & - & 56946.81 & 141881.23 \\
\hline
\end{tabular}

F D: Factor of discount; r: interest rate; Oper C.: operational costs=Total C.: Total costs.

Table 5 presents the results of the economic profitability indicators analyzed in this study (benefit/cost ratio (B/C), present net value (VPL) and internal rate of return (TIR)) as a function of each treatment at an interest rate of $2 \%$ per year and funded investment in eight years. The results 
demonstrate financial viability associated with the cultivation of passion fruit with systematic differentiation of irrigation schedules, with treatment with high financial returns to Pronaf producers providing an excellent alternative investment to the region.

TABLE 5. Values of different indicators of economic profitability analyzed according to the treatments.

\begin{tabular}{cccc}
\hline Treatments & B/C & VPL $(\mathrm{R} \$)$ & TIR $(\%)$ \\
\hline $\mathrm{T}_{1}$ & 1.723 & 41693.58 & 72.26 \\
$\mathrm{~T}_{2}$ & 1.669 & 38571.71 & 66.85 \\
$\mathrm{~T}_{3}$ & 1.330 & 18944.64 & 33.05 \\
$\mathrm{~T}_{4}$ & 1.360 & 20205.38 & 35.95 \\
$\mathrm{~T}_{5}$ & 2.491 & 84934.42 & 149.15 \\
\hline Means & 1.715 & 40869.95 & 71.45 \\
\hline
\end{tabular}

The results obtained according to the decision criteria show that all treatments are presented economically viable, given that the benefit/cost ratio was always higher than one unit and the TIR was above the interest rate of financing, particularly for $\mathrm{T}_{5}$ treatment. The high values of the analyzed variables verified in the treatment $T_{5}$ are related to higher productivity observed in this treatment, since production costs remained virtually unchanged for all treatments.

The benefit/cost ratio associated with the treatment $T_{5}$ indicates that for every $\mathrm{R} \$ 1.00$ invested in the culture is generated a net profit of $\mathrm{R} \$ 1.491$. The high financial return can be justified because of the low interest rate for family farmers through the Program for Strengthening Family Agriculture, Pronaf.

ARÊDES et al. (2009), analyzing profitability indicators of irrigation in the cultivation of passion fruit tree found $\mathrm{B} / \mathrm{C}$ ratio of 1.24 for irrigated production and 1.09 for unirrigated conditions, a value close to those found in some treatments of this research, however for irrigated production. KOETZ (2006) evaluated two types of crops for growing passion fruit tree in the conditions of Lavras city - Paraná (PR) state, in Brazil; and found benefit/cost ratio of R\$2.58 and $\mathrm{R} \$ 2.57$ for cultivation in protected and natural environments, respectively.

The VPL results indicate that the current values for the investment plan calculated based on the opportunity costs of capital, would overcome the values of alternative investments, with earnings of $\mathrm{R} \$ 18,944.64$ to $\mathrm{R} \$ 84,934.43$ for the worst and best treatment, respectively, at an interest rate of $2 \%$ per year.

ARÊDES et al. (2009) on the economic analysis of irrigation in the cultivation of passion fruit tree obtained values of VPL of R\$29,907.82 and R\$ 19,929.57 for crops on irrigated and unirrigated conditions, respectively, at an interest rate of $10.82 \%$ per year.

As the other indicators of profitability, the more attractive internal rate of return (TIR) is also associated with treatment $\mathrm{T}_{5}$, although all treatments have demonstrated economic viability at a discount rate of $2 \%$ per year, values higher than those obtained by ARÊDES et al. (2009) who obtained values of TIR equivalent to $52.82 \%$ and $72.94 \%$ for unirrigated and irrigated crops, respectively.

In order to verify the behavior of the profitability indicators for other discount rates on the market, we carried out a sensitivity analysis, whose results are presented in Table 6. Through this analysis we observe that even at high interest rates, investments in most treatments remain economically viable, showing consistency in returns from the investment.

We compared the risks of financial investment in the production of passion fruit to other forms of agricultural production, such as the dairy cattle studied by PERES et al. (2009) who 
verified the feasibility of producing only the lower interest rates at $8 \%$ per year. However, we observed that the risk of financial failure of this crop is very small since the behavior towards other interest rates shows indifference to some treatments. ENGINDENIZ1 \& GÜL (2009) point out that the production market risks affect the profitability and economic viability of the cultures, as the authors found in the production of vegetables.

TABLE 6. Sensitivity analysis of the profitability indicators according to alternative discount rates.

\begin{tabular}{|c|c|c|c|c|c|c|c|c|c|}
\hline \multirow{2}{*}{\multicolumn{3}{|c|}{ Interest rates per year $(\%)$}} & \multicolumn{4}{|c|}{$\mathrm{T}_{1}$} & \multicolumn{3}{|c|}{$\mathrm{T}_{2}$} \\
\hline & & $\mathrm{B} / \mathrm{C}$ & \multicolumn{2}{|c|}{ VPL $(\mathrm{R} \$)$} & \multicolumn{2}{|c|}{ TIR (\%) } & $\mathrm{B} / \mathrm{C}$ & VPL (R\$) & $\operatorname{TIR}(\%)$ \\
\hline \multicolumn{2}{|r|}{0} & 1.756 & \multicolumn{2}{|c|}{45824.12} & \multicolumn{2}{|c|}{75.63} & 1.701 & 42481.64 & 70.11 \\
\hline \multicolumn{2}{|r|}{2} & 1.723 & \multicolumn{2}{|c|}{41693.58} & \multicolumn{2}{|c|}{72.26} & 1.669 & 38571.71 & 66.85 \\
\hline \multicolumn{2}{|r|}{5} & 1.671 & \multicolumn{2}{|c|}{36259.58} & \multicolumn{2}{|c|}{67.13} & 1.619 & 33424.17 & 61.88 \\
\hline \multicolumn{2}{|r|}{10} & 1.585 & \multicolumn{2}{|c|}{28811.96} & \multicolumn{2}{|c|}{58.50} & 1.535 & 26360.08 & 53.52 \\
\hline \multicolumn{3}{|c|}{15} & \multicolumn{2}{|c|}{22867.29} & \multicolumn{2}{|c|}{49.96} & 1.452 & 20711.21 & 45.25 \\
\hline \multicolumn{2}{|r|}{20} & 1.417 & \multicolumn{2}{|c|}{18011.76} & \multicolumn{2}{|c|}{41.66} & 1.372 & 16087.92 & 37.21 \\
\hline \multicolumn{2}{|r|}{ Means } & 1.609 & \multicolumn{2}{|c|}{32244.72} & \multicolumn{2}{|c|}{60.86} & 1.558 & 29606.12 & 55.8 \\
\hline \multicolumn{3}{|c|}{$\mathrm{T}_{3}$} & \multicolumn{4}{|c|}{$\mathrm{T}_{4}$} & \multicolumn{3}{|c|}{$\mathrm{T}_{5}$} \\
\hline $\mathrm{B} / \mathrm{C}$ & VPL (R\$) & TIR (\%) & $\mathrm{B} / \mathrm{C}$ & \multicolumn{2}{|c|}{ VPL (R\$) } & TIR (\%) & $\mathrm{B} / \mathrm{C}$ & VPL (R\$) & $\operatorname{TIR}(\%)$ \\
\hline 1.357 & 21466.56 & 35.67 & 1.387 & \multicolumn{2}{|c|}{22813.17} & 38.67 & 2.541 & 92118.44 & 154.07 \\
\hline 1.330 & 18944.64 & 33.05 & 1.360 & \multicolumn{2}{|c|}{20205.38} & 35.95 & 2.491 & 84934.42 & 149.15 \\
\hline 1.291 & 15599.65 & 29.07 & 1.318 & 1674 & 9.49 & 31.82 & 2.416 & 75535.91 & 141.65 \\
\hline 1.224 & 10949.42 & 22.37 & 1.249 & 1195 & 2.25 & 24.87 & 2.290 & 62781.28 & 129.05 \\
\hline 1.157 & 7162.89 & 15.74 & 1.180 & 805 & & 18.01 & 2.166 & 52744.57 & 116.58 \\
\hline 1.093 & 4002.20 & 9.31 & 1.114 & 480 & & 11.37 & 2.045 & 44677.59 & 104.49 \\
\hline 1.242 & 13020.89 & 24.20 & 1.268 & 1409 & 5.94 & 26.78 & 2.325 & 68798.70 & 132.50 \\
\hline
\end{tabular}

Treatments $T_{3}$ and $T_{4}$ do not demonstrate economic viability for the financing conditions to rates prevailing in the market, whose interest in the long-term are around 15\%, historically. On the other hand, for the $T_{1}$ and $T_{2}$, although demonstrate economic viability for the interest rates prevailing in the market, we would recommend the presentation of more attractive alternatives to farmers. The TIR value associated with the $\mathrm{T}_{5}$ treatment proved to be a consistent investment with high return rate.

\section{CONCLUSIONS}

The highest fruit yield $\left(16,660 \mathrm{~kg} \mathrm{ha}^{-1}\right)$ was obtained from the fractionation of irrigation twice daily $(50 \%$ at $7 \mathrm{~h}$ and $50 \%$ at $21 \mathrm{~h} 30)$. This treatment showed an increase in the productivity level of around 54\% compared to treatment with lower productivity.

The cultivation of passion fruit tree irrigated in different times proved to be financially viable and highly profitable to the interest rate of $2 \%$ per year, showing low sensitivity of financial risk to real interest rates above the prevailing market.

The higher economic returns were obtained from the fractionation of irrigation twice daily (50\% at $7 \mathrm{~h}$ and $50 \%$ at $21 \mathrm{~h} 30$ ), presenting economic viability even for the highest interest analyzed.

\section{REFERENCES}

ARAÚJO, H.F.; COSTA, R.N.T.; CRISÓSTOMO, J.R.; SAUNDERS, L.C.U.; MOREIRA, O.C.; MACEDO, A.B.M. Produtividade e análise de indicadores técnicos do maracujazeiro-amarelo 
irrigado em diferentes horários. Revista Brasileira de Engenharia Agrícola e Ambiental, Campina Grande, v.16, n.2, p.159-164, 2012.

ARAÚJO NETO, S.E.; RAMOS, J.D.; ANDRADE JÚNIOR, V.C.; RUFINI, J.C.M.; MENDONÇA, V.; OLIVEIRA, T.K. Adensamento, desbaste e análise econômica na produção do maracujazeiro-amarelo. Revista Brasileira de Fruticultura, Jaboticabal, v. 27, n. 3, p. 394-398, 2005.

ARÊDES, F.A.; PEREIRA, M.W.G.; GOMES, M.F.M.; RUFINO, J.L.S. Análise econômica da irrigação na cultura do maracujá. Revista de Economia da Universidade Estadual de Goiânia, Anápolis, v. 05, n. 01, p. 67-86, 2009.

BORGES, A.L. Nutrição mineral, calagem e adubação. In: ADELISE. A.L.; MARIO, A.P.C. Maracujá: Produção e qualidade na passicultura. Cruz Das Almas: Embrapa, 2004. cap. 7, p. 119149.

CARVALHO, J.A.; KOETZ, M.; SOUSA, A.M.G.; SOUZA,K.J. Desenvolvimento e produtividade do maracujazeiro-amarelo irrigado sob diferentes lâminas de irrigação em ambiente protegido e natural. Engenharia Agrícola, Jaboticabal, v.30, n.5, p. 862-874, 2010.

ENGINDENIZ, S.; GÜL, A. Economic analysis of soilless and soil-based Greenhouse cucumber production in turkey. Scientia Agrícola, Piracicaba, v.66, n.5, p.606-614, 2009.

IBGE. Instituto Brasileiro de Geografia e Estatística. Agricultura. Produção agrícola municipal, 2010. Disponível em: < http://www.sidra.ibge.gov.br> Acesso em: 4 jul. 2012.

KOETZ, M. Maracujazeiro-amarelo: cultivo protegido e natural, irrigação e adubação potássica. 2006. 130 f. Tese (Doutorado em Engenharia agrícola) - Centro de Ciências e Tecnologias da Universidade Federal de Lavras, Lavras, 2006.

MENEGHETTI, A.M.; NÓBREGA, L.H.P.; SANTOS, R.F. Manejo da irrigação para produção de minimilho por evapotranspiração. Engenharia na Agricultura, Viçosa-MG, v.16, n.3, 351-358, 2008.

MONTEIRO, R.O.C.; COSTA, R.N.T.; LEÃO, M.C.S.; AGUIAR, J. V. Aspectos econômicos da produção de melão submetidos a diferentes lâminas de irrigação e doses de nitrogênio. Irriga, Botucatu, v.12, n.3, p.364-376, 2007.

PERES, A.A.C.; VÁSQUEZ, H.M.; SOUZA, P.M.; SILVA, J.F.C.; VILLELA, O.V.; SANTOS, F.C. Análise financeira e de sensibilidade de sistemas de produção de leite em pastagem. Revista Brasileira de Zootecnia, Viçosa-MG, v.38, n.10, p.2072-2078, 2009.

RIBEIRO, M.C.; FILHO, D.O.; ANTÔNIO A. SOARES, A.A.; MARTINS, J.H.; MANTOVANI, E.C. Tarifa binômia para o custo de água pressurizada em perímetros Irrigados. Engenharia Agrícola, Jaboticabal, v.30, n.4, p. 578-586, 2010.

SAEED, I.A.M.; EL-NADI, A.H. Irrigation effects on the growth, yield and water use efficiency of alfalfa. Irrigation Science, New York, v. 17, p. 63-68, 1997.

SANTANA, M.J.; CARVALHO, J.A.; ANDRADE, M.J.B.; BRAGA, J.C.; GERVÁCIO, G.G. Coeficiente de cultura e análise do rendimento do feijoeiro sob regime de irrigação. Irriga, Botucatu, v.13, n.1, p.92-112, 2008.

SDA. Secretaria do Desenvolvimento Agrário. Desenvolvimento da agricultura familiar - Projeto horo-sazonal "energia rural mais barata”, 2009. Disponível em:

$<$ http://www.sda.ce.gov.br/categoria2/paginas/desenvolvimento-da-agriculturafamiliar/?searchterm=horo-sazonal>. Acesso em: 25 nov. 2010.

SOUZA, M.S.M.; BEZERRA, F.M.L.; VIANA, T.V.A.; TEÓFILO, E.M.; CAVALCANTE, Í.H.L. Evapotranspiração do maracujá nas condições do vale do curu. Caatinga, Mossoró, v.22, n.2, p.11$16,2009$. 
SEBRAE. Serviço Brasileiro de Apoio às Micro e Pequenas Empresas. Cartilha de acesso ao pronaf, 2010. Disponível em: <htt//www.sebrae.gov.br >. Acesso em: 14 out. 2010. 